\title{
QUATERNARY EQUILIBRIUM LINE ALTITUDE ESTIMATION BY DIFFERENT METHODS IN THE ALVAND MOUNTAIN OF HAMEDAN, IRAN
}

\author{
JAFARI, GH. H. ${ }^{1 *}-$ BARATI, Z. ${ }^{2}$ \\ ${ }^{I}$ Department of Geography, Faculty of Humanities, University of Zanjan, Zanjan, Iran \\ (Phone: +98-24-3305-4176; fax: +98-24-3228-3201) \\ ${ }^{2}$ Master of Hydrogeomorphology, University of Zanjan, Zanjan, Iran \\ (Phone: +98-469-2329) \\ *Corresponding author \\ E-mail: jafarihas@znu.ac.ir \\ (Received 28 ${ }^{\text {th }}$ May 2018; accepted $31^{\text {st }}$ Aug 2018)
}

\begin{abstract}
From the early Quaternary, external factors such as climate change have altered the surface of the earth. The climatic changes have led to increase or decrease of glacier in highlands of Iran. The Alvand Mountain with an altitude of $3500 \mathrm{~m}$ is one of Iran's highlands, which is located in Hamedan Provence. In order to the equilibrium line altitude (ELA) estimate during the last glacial maximum (LGM) in Alvand Mountain, this paper has used five methodological approaches such as Wright, slopedirection (SD), curvature coefficient (CC), the accumulation-area ratio (AAR), and terminus to head altitude ratio (THAR). After estimating ELA through the aforementioned methods, ELA in the northeast and southwest slopes were compared. According to the ELA estimates require the identification of Quaternary glacier circuses. The cirques in southwest slopes had an altitude between of 1700 to $2900 \mathrm{~m}$ and in northeast slopes had an altitude between of 2000 to $3400 \mathrm{~m}$. The estimation of ELA of the whole study area turned out to be $2294 \mathrm{~m}$. In the SD method, the average ELA in the northeast and the southwest slopes was 1960 and $2491 \mathrm{~m}$, respectively. In the CC method, the ELA of the northeast and the southwest slopes was 2167 and $2099 \mathrm{~m}$, respectively. The results of ELA analysis indicate that there are differences between the northeast and southwest slopes. According to Wright and CC methods, ELA in the northeast is higher than the southwest slopes, which is against the natural order of the environment. ELA estimated by AAR and SD methods in the northeast slopes is lower than in the southwest slopes. According to these two methods, there is about $500 \mathrm{~m}$ difference between the ELA of the northeast and southwest slopes. In this paper, in addition to the ELA, the water and ice equilibrium line altitude (WIELA) have been estimated. The field observation of the moraines revealed that WIELA during LGM was located at 1680 and $1776 \mathrm{~m}$ in the northeast and southwest slopes, respectively.
\end{abstract}

Keywords: Alvand, curvature coefficient, glacial Quaternary, slope-direction, Wright

\section{Introduction}

The Quaternary period represents the past 2.58 million years and is officially subdivided into the Pleistocene and Holocene epochs, with the base of the Holocene aging 11,700 calendar years before 2000 AD (Head and Gibbard, 2014). The Quaternary is characterized by repeated cycles of cold-warm climatic oscillations as the Earth alternated between glacial and retreating continental modes. Glacial -interglacial climate changes during the Quaternary were largely controlled by cyclic variations in the amount of solar radiation, or solution received in middle to high latitudes of the northern hemisphere (Bondarenko et al., 2013). The study of glaciers is of great importance for understanding and predicting global environmental changes (Knight, 2006). Climatic cold phases and future changes can be predicted by investigating the glacier advances (Abramowski et al., 2006; Solomina et al., 2004). Due to the different 
nature of glaciers depending on the areas and their physiographic features, the various evidence is remarkable for glacier processes (Stroeven et al., 2013). As glaciers move across the Earth's surface, they erode and transport sediments. Ice sheets and glaciers are, therefore, powerful agents of erosion that are manifested in the grandeur of, e.g., glacial cirques and valleys (Jafari, 2013). Landforms resulted from glacial erosion are mostly detected in an area where the summits are 300-400 m higher than those of the equilibrium line altitudes (ELA) during the Quaternary cold periods (Zomorodian, 2012; JedariEivazi, 2011). The ELAs are the elevation across the glacier where the annual net balance is zero. "The equilibrium line indicates the position where, over a period of one year, accumulation of snow is exactly balanced by ablation" (Benn and Lehmkuhl, 2000). ELA is a statistical concept representing the line dividing the accumulation and ablation zones. The ELA of glaciers is particularly sensitive to changes in summer temperature and winter precipitation (Ohmura et al., 1992; Paterson, 1994; Nesje and Dahl, 2000; Osmaston, 2005). The ELA of a glacier separates the accumulation zone (where the annual mass balance is $>0$ ) from the ablation zone (where the annual mass balance is <0). These changes are commonly summarized by the fluctuations in the ELA (the dividing line between a glacier's accumulation and ablation areas). There is substantial controversy regarding the interpretation of changes in mountain glacial extent during the last glacial maximum (LGM). The LGM is in the Quaternary history when world glaciers reaching their maximum integrated volume (Clark et al., 2009). The LGM was the period when the Scandinavian, Irish, British and Laurentide ice sheets were at their maximum extent, coinciding with the period of lower sea level (approximately $130 \mathrm{~m}$ relative to the current sea level) (Yokoyama et al., 2000).

\section{Review of literature}

Regarding the context of this study, the geographical position of Iran and its climate limited the extension of continental glaciers. In fact, Iran's geographical position, i.e. 25 to $40 \mathrm{~N}$ and its arid and semi-arid climate have put a limitation on the formation of glaciers. Vaziri (2003) estimated the ELAs of present glaciers in some high mountains of Iran, including Damavand $(5610 \mathrm{~m})$, Alamkouh $(4850 \mathrm{~m})$, Sabalan $(4811 \mathrm{~m})$, Oshtorankouh $(4090 \mathrm{~m})$, and Zardkouh $(4221 \mathrm{~m})$. Several researchers have estimated the ELA of the glacier Quaternary, some of them are referred to in Table 1.

Many geomorphologists have studied the late Quaternary glaciers of Iran using Wright method. This method affects the topography and altitude of mountain sinusitis (The mountain knick point). In regions which mountain sinusitis is higher than ELA, the recognition of cirques becomes troublesome. This ends with not being able to estimate the exact ELA. In order to solve this problem, various methods have been compared in this article (Slope-direction (SD), curvature coefficient (CC), altitude- ratio (AR), accumulation-area ratio method (THAR) and Wright methods during the LGM to estimate ELA).

\section{Materials and methods}

The study area of this research is known as Alvand batholith. It is located in the vicinity of Hamedan province, Iran, with an area of $1375 \mathrm{~km}^{2}$. This batholith belongs to the Quaternary and has been created by igneous masses. This area is made up of 
intrusive granite rock, shale, siltstone, and schist of the Jurassic. It is surrounded from two directions: from the northwest by Khodabandehlu, Sanandaj, and Chehelcheshmeh Mountains, and from the southeast by Rasund Highlands and Vafs Mountains in the Central Province. The mountain is oriented to NW-SE directions and divides Hamedan Province into northern and southern halves. The Alvand Batholith is located between $48^{\circ}-48.6^{\circ} \mathrm{E}$ and $34.5^{\circ}-34.85^{\circ} \mathrm{N}$. The highest and the lowest parts of the study area had 3574 and $1700 \mathrm{~m}$ altitude, respectively (Fig. 1).

Various methods of reconstructing ELAs have been critically reviewed (Meirding, 1982; Benn and Evans, 1998; Porter, 2001; Kaser and Osmaston, 2002; Osmaston, 2005). In order to reconstruct ELA, Wright, slope- direction (SD), curvature coefficient (CC), altitude- ratio (AR), and accumulation-area ratio method (AAR) methods were employed in this project. To this end, cirques altitude and extent of the glacier tongues were determined in both northern and southern slopes. The topographic 1: 50,000 scale maps were provided, and the study area was also divided into 28 sub-basins. All this information was recorded through direct observations and field surveys. In the next step, the results of the field surveys and Quaternary landform processes were considered together and combined with the geomorphological, topographic, and geological results.

Table 1. Researchers of glacial geomorphology of Iran

\begin{tabular}{|c|c|c|}
\hline Researcher & Year & Region \\
\hline Bobek & 1934 & Alborz and Kurdistan \\
\hline Desio & 1934 & Zardkouh \\
\hline Bobek & 1963 & Iran \\
\hline Yamani & 2002 & Alamkouh \\
\hline Tahoni & 2005 & Talesh \\
\hline Moghimi & 2008 & Damavand Mountain \\
\hline Mahmudi & 2008 & West of Iran (Kurdistan Province) \\
\hline Yamani & 2007 & Zardkouh \\
\hline Zomorodian & 2012 & Iran \\
\hline Ramesht and Shoshtari Zadeh & 2007 & Salafchegan Mountain \\
\hline Yamani & 2007 & Zard-kuh \\
\hline Yamani et al. & 2007 & Karkas Mountain \\
\hline Yamani and Zamani & 2007 & In the Shahrestanac valley (Alamkouh Mountain) \\
\hline Ramesht and Kazemi & 2007 & Bol Mountain \\
\hline Almodaresi and Ramesht & 2007 & Shirkouh Mountain \\
\hline Moayeri et al. & 2008 & Safashahr Mountain \\
\hline Nojavan et al. & 2009 & Shirkouh Mountain \\
\hline Esfandiari Dur Abadi & 2009 & Sabalan \\
\hline Zamani & 2009 & Jajroud and Karaj Mountain \\
\hline Amirahmadi et al. & 2011 & Eghlid Aspas plain \\
\hline Yamani et al. & 2011 & Jajroud and Karaj Mountain \\
\hline Abtahi & 2014 & Jajroud basin \\
\hline Parizi et al. & 2014 & Tangoeye Sirjan \\
\hline Jafari and Asghari & 2014 & Zabjanroud \\
\hline Jafarbiglo et al. & 2014 & Bidkhun Kerman \\
\hline Seife et al. & 2015 & Shirkouh Mountain \\
\hline Sharifi and Farah Bakhsh & 2015 & Shirkouh Mountain \\
\hline Khosravi et al. & 2016 & Binalud Mountain \\
\hline
\end{tabular}




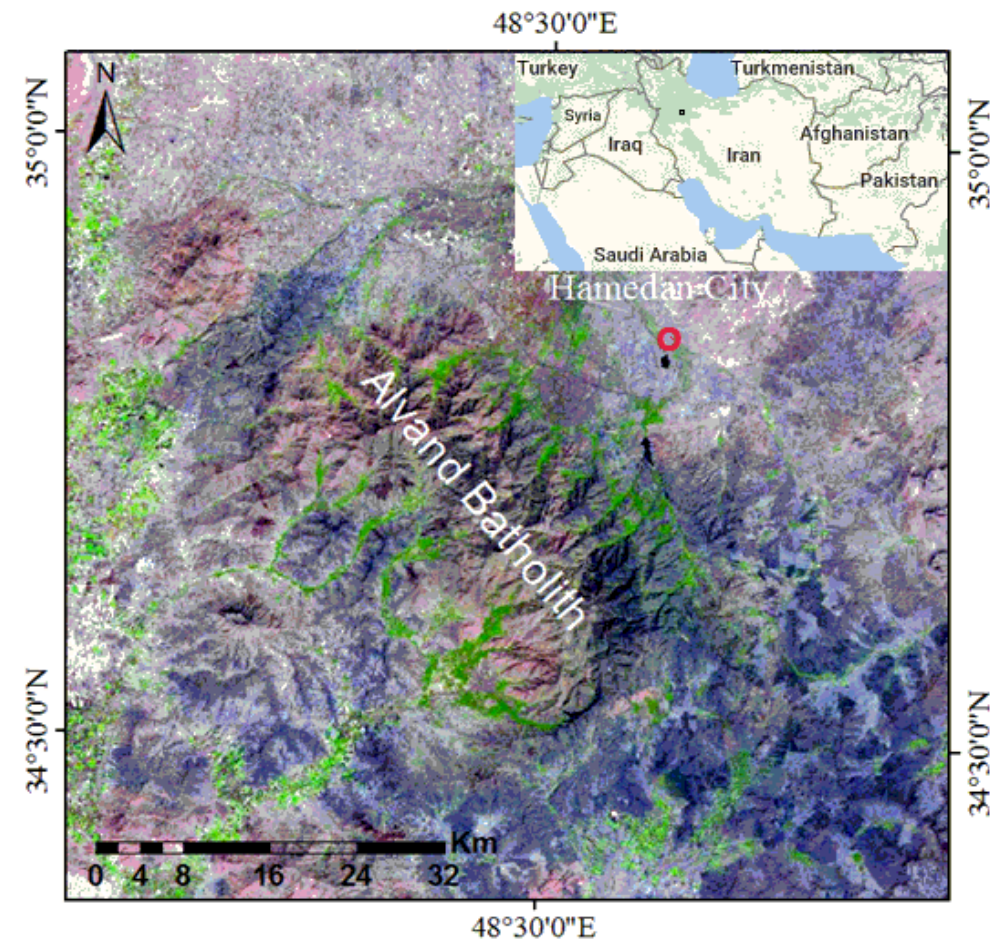

Figure 1. The position in the study area

\section{Wright method}

This method estimates ELA by determining the location and altitude of $60 \%$ of cirques above the line. Above this, the annual snowfall is more than the melting of annual, and below this altitude, the snowfall is less than the melting of annual. For estimating ELA, the altitude of identifying cirques is sorted based on descending order. Then the number of cirques is multiplied to $60 \%$ (Eq. 1) (Ramesht and Nematollahi, 2005; Ramesht and Shahzeidi, 2011; Ghahroudi Tali et al., 2013; Abtahi, 2014). The gained number represents a numerical line of cirques in which ELA is located. In the following, $\mathrm{X}$ shows the number of rows and $\mathrm{N}$ is cirques number (Porter, 2001).

$$
X=N \times 0.6
$$

The northeast and southwest slopes of sub-basins are separated using topographic maps, and cirques are determined in each slope.

\section{Slope-direction (SD) method}

Mountainous topography is constructed through a variety of interacting processes. In addition to other geomorphic processes, in many mountainous region's topography has been affected by glacier erosion (Headley and Ehlers, 2015). Among several factors, which influence ELA location, two important factors are determinate in SD Method. One of these factors is mountains' slope direction. A shady mountain slope will have a lower ELA than the one which receives more solar energy. Wind is another factor because it produces snow drifts on the leeward side of mountain ranges. In the middle latitudes of the Northern Hemisphere, ELA is lower on the north (shaded) and east 
(leeward) slopes. Consequently, the most significant glacier development in this region is on north-facing and east-facing slopes (Petersen et al., 2008).

The principal reason for naming this method as SD is that ELA is estimated based on differences between mountain slope and their directions; besides these two elements, the latitude and longitude of the pikes must be calculated. This method depends on the solar elevation angle which varies according to the direction and slope of the mountains. In order to apply this method in Iran's context, appropriate equation was defined according to the prevailing geographical direction in 16 polygons. Which was determined considering the 16 Iran climate stations, and 8 acquisitions were defined in 16 geographical directions (Jafari, 2013). The reason why 8 equations were used for 16 directions is that the solar elevation angles in symmetric directions were equal. For example, the solar elevation angles are similar to each other in the southwest to southeast or in the northwest to northeast provided that the amount of slope is equal. Slope value is estimated by using $30 \mathrm{~m}$ Digital Elevation Mountain (DEM) of the area, and aspect is determined along with the main mountainous region. To this end, the slope maps were prepared separately for the northeast and southwest slopes. Based on slope maps, Equation 2 was used to estimate the average slope in percent.

$$
S=\frac{\Sigma(s x)}{A}
$$

In this equation $\mathrm{S}$ is the average slope (\%), $s$ is the slope of each pixel, $\mathrm{x}$ is the area of each pixel in the slope map, and A is the total area. Jafari (2009) has estimated 144 equations in main and secondary directions on the basis of the slope and 16 Polygon Radiometers of Iran (Table $2 a$ and $b$ ) (Moayeri et al., 2011).

Table 2a. Temperature equations with slope in different directions of Iran (Moayeri et al., 2011)

\begin{tabular}{|c|c|c|c|c|c|c|c|c|c|c|c|c|}
\hline \multirow{2}{*}{ City } & \multirow{2}{*}{ Station altitude } & \multirow{2}{*}{ Latitude } & \multirow{2}{*}{ Altitude } & \multirow{2}{*}{$\begin{array}{c}\text { Station } \\
\text { temperature }\end{array}$} & \multicolumn{2}{|l|}{ SE or SW } & \multicolumn{2}{|c|}{ SE or SW } & \multicolumn{2}{|c|}{ NNE or NNW } & \multicolumn{2}{|c|}{ SSE or SSW } \\
\hline & & & & & $\mathbf{T}=$ & $\mathbf{R}^{2}$ & $\mathbf{T}=$ & $\mathbf{R}^{2}$ & $\mathbf{T}=$ & $\mathbf{R}^{2}$ & $\mathbf{T}=$ & $\mathbf{R}^{2}$ \\
\hline Ahvaz & 22.5 & 48.69 & 31.32 & 25 & $24.94-0.11 \mathrm{~s}$ & 1 & $25.33+.08 \mathrm{~s}$ & .98 & $25.18-.18 \mathrm{~s}$ & 1 & $25.56+.09 \mathrm{~s}$ & .96 \\
\hline Birjand & 1491 & 59.22 & 32.88 & 16.4 & $16.7-.12 \mathrm{~s}$ & 1 & $17.15+0.9 \mathrm{~s}$ & .98 & $16.29-.16 \mathrm{~s}$ & .99 & $17.33+.1 \mathrm{~S}$ & .97 \\
\hline Bakhtaran & 1322 & 47 & 34.31 & 14.5 & $14.41-0.12 \mathrm{~s}$ & 1 & $14.79+.09 \mathrm{~s}$ & .99 & $14.63-.18 \mathrm{~s}$ & 1 & $15+.1 \mathrm{~S}$ & .97 \\
\hline Bujnord & 1091 & 57.32 & 37.47 & 13.1 & $13.12-.11 \mathrm{~s}$ & .99 & $13.56+.09 \mathrm{~s}$ & .99 & $13.36-.17 \mathrm{~s}$ & 1 & $13.76+.1 \mathrm{~S}$ & .98 \\
\hline Esfahan & 1600 & 51.67 & 32.64 & 16.1 & $16.01-.12 \mathrm{~s}$ & 1 & $16.44+.08 \mathrm{~s}$ & .98 & $16.25-.18 \mathrm{~s}$ & 1 & $16.65+.09 \mathrm{~S}$ & .96 \\
\hline Hamedan & 1749 & 48.52 & 34.8 & 10.98 & $10.84-.11 \mathrm{~s}$ & 1 & $11.27+.09 \mathrm{~s}$ & .99 & $11.09-.18 \mathrm{~s}$ & 1 & $11.49+.1 \mathrm{~s}$ & .97 \\
\hline Kerman & 1754 & 57 & 30.29 & 15.6 & $15.68-.12 \mathrm{~s}$ & 1 & $16.01+.08 \mathrm{~s}$ & .98 & $15.95-.19 \mathrm{~s}$ & 1 & $16.22+.09 \mathrm{~s}$ & .95 \\
\hline Mashhad & 990 & 59.6 & 36.28 & 13.8 & $14.8-.11 \mathrm{~s}$ & 1 & $15.25+.09 \mathrm{~s}$ & .99 & $15.05-.18 \mathrm{~s}$ & 1 & $15.44+.1 \mathrm{~s}$ & .97 \\
\hline Uromieh & 1312 & 45 & 37.55 & 11.4 & $11.04-.1 \mathrm{~s}$ & .99 & $11.46+.08 \mathrm{~s}$ & .99 & $11.27-.16 \mathrm{~s}$ & 1 & $11.64+.09 \mathrm{~s}$ & .98 \\
\hline Shiraz & 1488 & 52.53 & 29.61 & 17.5 & $17.41-.11 \mathrm{~s}$ & 1 & $17.81+.07 \mathrm{~s}$ & .98 & $17.65-.18 \mathrm{~s}$ & 1 & $18.01+.08 \mathrm{~s}$ & .95 \\
\hline Ramsar & 20 & 50.66 & 36.9 & 22.3 & 21.99-.1s & .99 & $22.42+.09 \mathrm{~s}$ & .99 & $22.23-.17 \mathrm{~s}$ & 1 & $22.62-.1 \mathrm{~s}$ & .98 \\
\hline Tabas & 711 & 56.92 & 33.58 & 21.3 & $21.84-.12 \mathrm{~s}$ & 1 & $22.31+.09 \mathrm{~s}$ & .98 & $22.11-.2 \mathrm{~s}$ & 1 & $22.53+.1 \mathrm{~s}$ & .97 \\
\hline Tabriz & 1361 & 46.4 & 38.07 & 12.2 & $11.79-.11 \mathrm{~s}$ & .99 & $12.24+.09 \mathrm{~s}$ & .99 & $12.03-.17 \mathrm{~s}$ & 1 & $12.44+.1 \mathrm{~s}$ & .98 \\
\hline Tehran & 1190 & 51.41 & 35.71 & 17 & $16.84-.12 \mathrm{~s}$ & 1 & $17.32+.1 \mathrm{~s}$ & .99 & $17.1-.19 \mathrm{~s}$ & 1 & $17.52+.11 \mathrm{~s}$ & .97 \\
\hline Yazd & 1230 & 54.35 & 31.88 & 18.8 & $18.74-.11 \mathrm{~s}$ & 1 & $19.15+.08 \mathrm{~s}$ & .98 & $18.37-.16 \mathrm{~s}$ & .99 & $19.17+.1 \mathrm{~s}$ & .98 \\
\hline Zanjan & 1663 & 48.47 & 36.67 & 10.9 & $10.63-.11 \mathrm{~s}$ & .99 & $11.1+.1 \mathrm{~s}$ & .99 & $10.88-.18 \mathrm{~s}$ & 1 & $11.31+.11 \mathrm{~s}$ & .98 \\
\hline
\end{tabular}


Table 2b. Temperature equations with slope in different directions of Iran (Moayeri et al., 2011)

\begin{tabular}{|c|c|c|c|c|c|c|c|c|c|c|}
\hline \multirow{2}{*}{ City } & \multicolumn{2}{|l|}{ North } & \multicolumn{2}{|l|}{ South } & \multicolumn{2}{|c|}{ WSW or ENE } & \multicolumn{2}{|c|}{ ESE or WSW } & \multicolumn{2}{|l|}{$\mathbf{W}$ or $\mathbf{E}$} \\
\hline & $\mathbf{T}=$ & $\mathbf{R}^{2}$ & $\mathbf{T}=$ & $\mathbf{R}^{2}$ & $\mathbf{T}=$ & $\mathbf{R}^{2}$ & $\mathbf{T}=$ & $\mathbf{R}^{2}$ & $\mathbf{T}=$ & $\mathbf{R}^{2}$ \\
\hline Ahvaz & $31.231-.5 \mathrm{~s}$ & 1 & $25.97+\mathrm{S}$ & .95 & $24.81-.04 \mathrm{~s}$ & .96 & $25.07+.06 \mathrm{~s}$ & 1 & $24.87 .02 \mathrm{~s}$ & .95 \\
\hline Birjand & $16.55-.2 \mathrm{~S}$ & .99 & $17.45+.1 \mathrm{~S}$ & .96 & $16.6-.04 \mathrm{~s}$ & .96 & $16.89+.07 \mathrm{~s}$ & 1 & $16.56+.03 \mathrm{~s}$ & .99 \\
\hline Bakhtaran & $14.78-.2 S$ & 1 & $15.07+.1 \mathrm{~S}$ & .96 & $14.3-.04 \mathrm{~s}$ & .96 & $14.55+.07 \mathrm{~s}$ & 1 & $14.36+.02 \mathrm{~s}$ & .95 \\
\hline Bujnord & $13.52-.2 \mathrm{~s}$ & 1 & $13.8+.1 \mathrm{~S}$ & .97 & $12.02-.03 \mathrm{~s}$ & .93 & $13.31+.07 \mathrm{~s}$ & 1 & $13.11+.03 \mathrm{~s}$ & .96 \\
\hline Esfahan & $16.4-.21 \mathrm{~S}$ & 1 & $16.74+.09 \mathrm{~S}$ & .95 & $15.9-.04 \mathrm{~s}$ & .96 & $16.17+.06 \mathrm{~s}$ & 1 & $15.95+.02 \mathrm{~s}$ & .95 \\
\hline Hamedan & $24.21-.11 \mathrm{~s}$ & 1 & $11.56+.1 \mathrm{~S}$ & .96 & $10.73-.04 \mathrm{~s}$ & .94 & $11.02+.07 \mathrm{~s}$ & 1 & $10.8+.02 \mathrm{~s}$ & .96 \\
\hline Kerman & $16.07-.21 \mathrm{~s}$ & 1 & $16.49+.09 \mathrm{~S}$ & .94 & $15.55-.04 \mathrm{~s}$ & .97 & $15.73+.06 \mathrm{~s}$ & 1 & $15.61+.02 \mathrm{~s}$ & .95 \\
\hline Mashhad & $15.2-.21 \mathrm{~S}$ & 1 & $15.51+.1 \mathrm{~S}$ & .97 & $14.71-.04 \mathrm{~s}$ & .94 & $15+.07 \mathrm{~s}$ & 1 & $14.78+.03 \mathrm{~s}$ & .96 \\
\hline Uromieh & $11.42-.19 \mathrm{~S}$ & 1 & $11.71+.1 \mathrm{~S}$ & .97 & $10.95-.03 \mathrm{~s}$ & .93 & $11.22+.06 \mathrm{~s}$ & 1 & $11.04+.02 \mathrm{~s}$ & .96 \\
\hline Shiraz & $17.78-.2 \mathrm{~S}$ & 1 & $18.09+.09 \mathrm{~S}$ & .94 & $17.29-.04 \mathrm{~s}$ & .97 & $17.55+.06 \mathrm{~s}$ & 1 & $17.34+.02 \mathrm{~s}$ & .96 \\
\hline Ramsar & $22.38-.2 \mathrm{~S}$ & 1 & $22.68+.1 \mathrm{~S}$ & .97 & $21.89-.03 \mathrm{~s}$ & .93 & $22.18+.07 \mathrm{~s}$ & 1 & $21.98+.03 \mathrm{~s}$ & .96 \\
\hline Tabas & $22.26-.23 \mathrm{~s}$ & 1 & $22.62+.1 \mathrm{~S}$ & .96 & $21.73-.04 \mathrm{~s}$ & .96 & $22.02+.07 \mathrm{~s}$ & 1 & $21.79+.02 \mathrm{~s}$ & .95 \\
\hline Tabriz & $12.12-.2 \mathrm{~S}$ & 1 & $12.52+.11 \mathrm{~S}$ & .97 & $11.71-.03 \mathrm{~s}$ & .92 & $12+.07 \mathrm{~s}$ & 1 & $11.79+.03 \mathrm{~s}$ & .95 \\
\hline Tehran & $17.27-22 \mathrm{~s}$ & 1 & $17.6+.11 \mathrm{~S}$ & .98 & $16.73-.04 \mathrm{~s}$ & .94 & $17.05+.07 \mathrm{~s}$ & 1 & $16.82+.03 \mathrm{~s}$ & .96 \\
\hline Yazd & $19.1-.21 \mathrm{~S}$ & 1 & $19.22+.11 \mathrm{~S}$ & .98 & $18.62-.04 \mathrm{~s}$ & .96 & $18.88+.06 \mathrm{~s}$ & 1 & $18.69+.02 \mathrm{~s}$ & .95 \\
\hline Zanjan & $11.06-.22 \mathrm{~s}$ & 1 & $11.38+.11 \mathrm{~S}$ & .97 & $10.52-.04 \mathrm{~s}$ & .93 & $10.83+.07 \mathrm{~s}$ & 1 & $10.62+.03 \mathrm{~s}$ & .96 \\
\hline
\end{tabular}

For Alvand Mountain, polygonal equations of Hamadan in the northeast and southwest have been used based on the direction of the slopes. Placing the calculated slope of the northeast slopes in Equation 3 and the southwest slopes in Equation 4, the annual average temperature was estimated for the related slope (Moayeri et al., 2011).

$$
\begin{aligned}
& \mathrm{T}=10.84-0.11 \mathrm{~S} \\
& \mathrm{~T}=11.27+0.09 \mathrm{~S}
\end{aligned}
$$

In the above equations, $T$ is temperature in degrees Celsius, and $S$ is the average slope in percentage. The estimated temperature in a thousand is multiplied, and the result is divided by the lapse rate of the region. Then the altitude of the base station is obtained. The estimated number is the contemporary ELA. According to the ELA estimated by Wright method and assuming zero temperature ${ }^{\circ} \mathrm{C}$, the contemporary temperature estimated for altitude was deducted from the temperatures estimated for the northeast (Eq. 3) and southwest slopes of the relationships (Eq. 4), and the result was multiplied in thousand and divided by the lapse rate of the region, resulting in the altitude of the base station. The estimated number is the ELA. Therefore, determining the altitude is necessary where the temperature (slope and specific direction) is equal to zero. Equation 5 was applied for this purpose.

$$
\mathrm{H}=\frac{\mathrm{T}: 1000}{\mathrm{Lr}}+h s
$$


In this equation, $H$ is altitude, $L r$ is the environmental temperature drop per thousand meters, and $h s$ is the altitude of the base station.

\section{Curvature coefficient (CC)}

Consideration of the contour line as the characteristics of topographic maps is an important step in the study of geomorphologic processes. Extensive glacial landforms related to valley glaciation are found in the study area, including glacial valleys, cirques (Fig. 2A and B), erratic block (Fig. 2C), Drumlin (Fig. 2D), and terminal moraines (Fig. $2 E$ in southwest and $\mathrm{F}$ in northeast slope). Glacial valleys have distinct $\mathrm{U}$-shaped cross-profiles, usually with a distinctive cirque at the valley head (Fu et al., 2013).
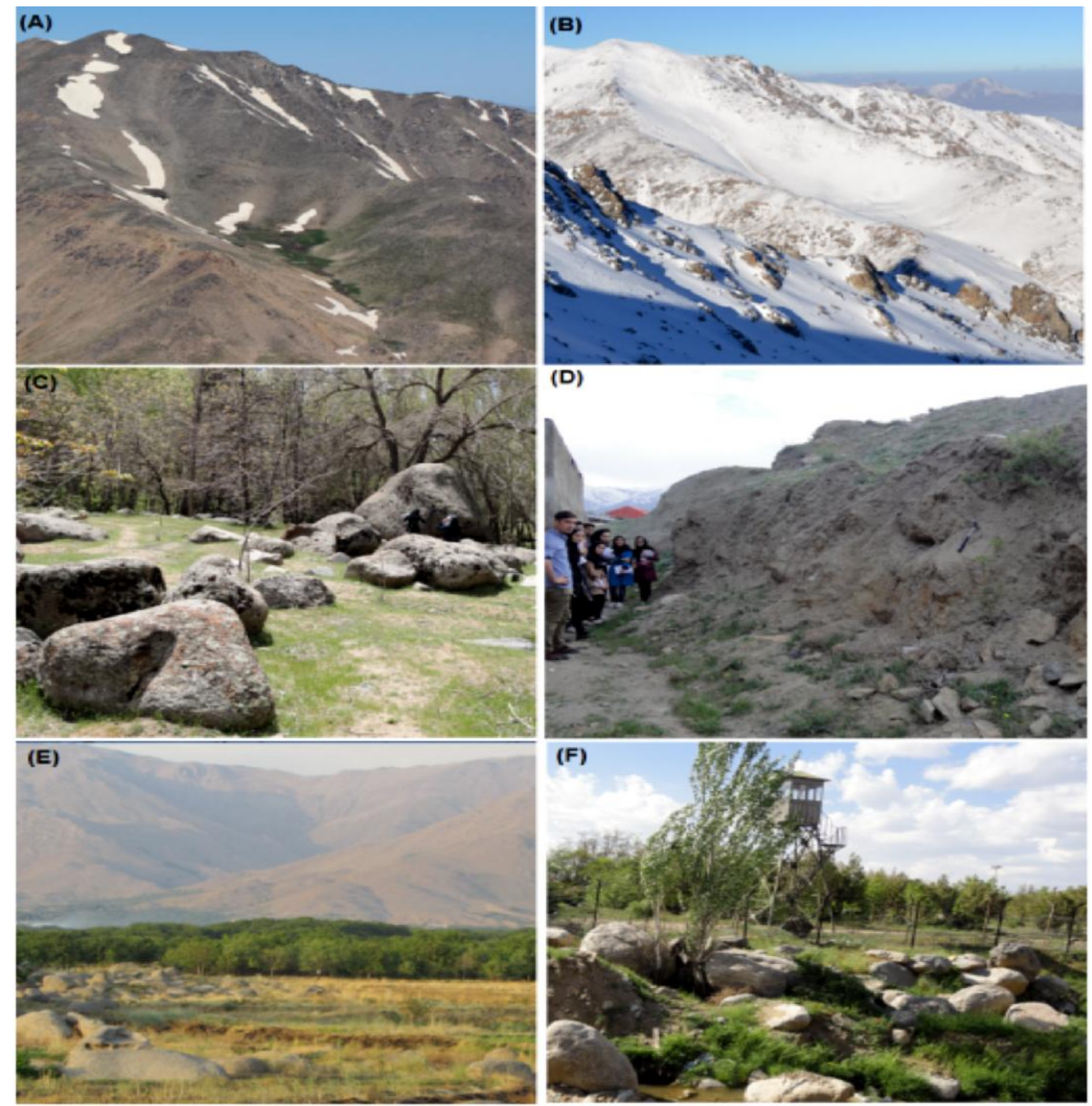

Figure 2. Glacial landforms in the Alvand Mountain

Steep mountain streams carve valleys in cross section that resemble the letter V (CC closer to zero). Since glaciers are much thicker than streams, they erode the sides as well as the bottom of these valleys, bowing the cross-sectional shape out to a U-shaped glacial trough (Gabler et al., 2017: 391) (CC is closer to one). 
The contour line in different slopes of Alvand Mountain was determined by $30-\mathrm{m}$ DEM. The mountain valleys were divided into 28 sub-basins by drawing a line along the mountain sinuosity on topographical maps 1.50000 (Fig. 3).

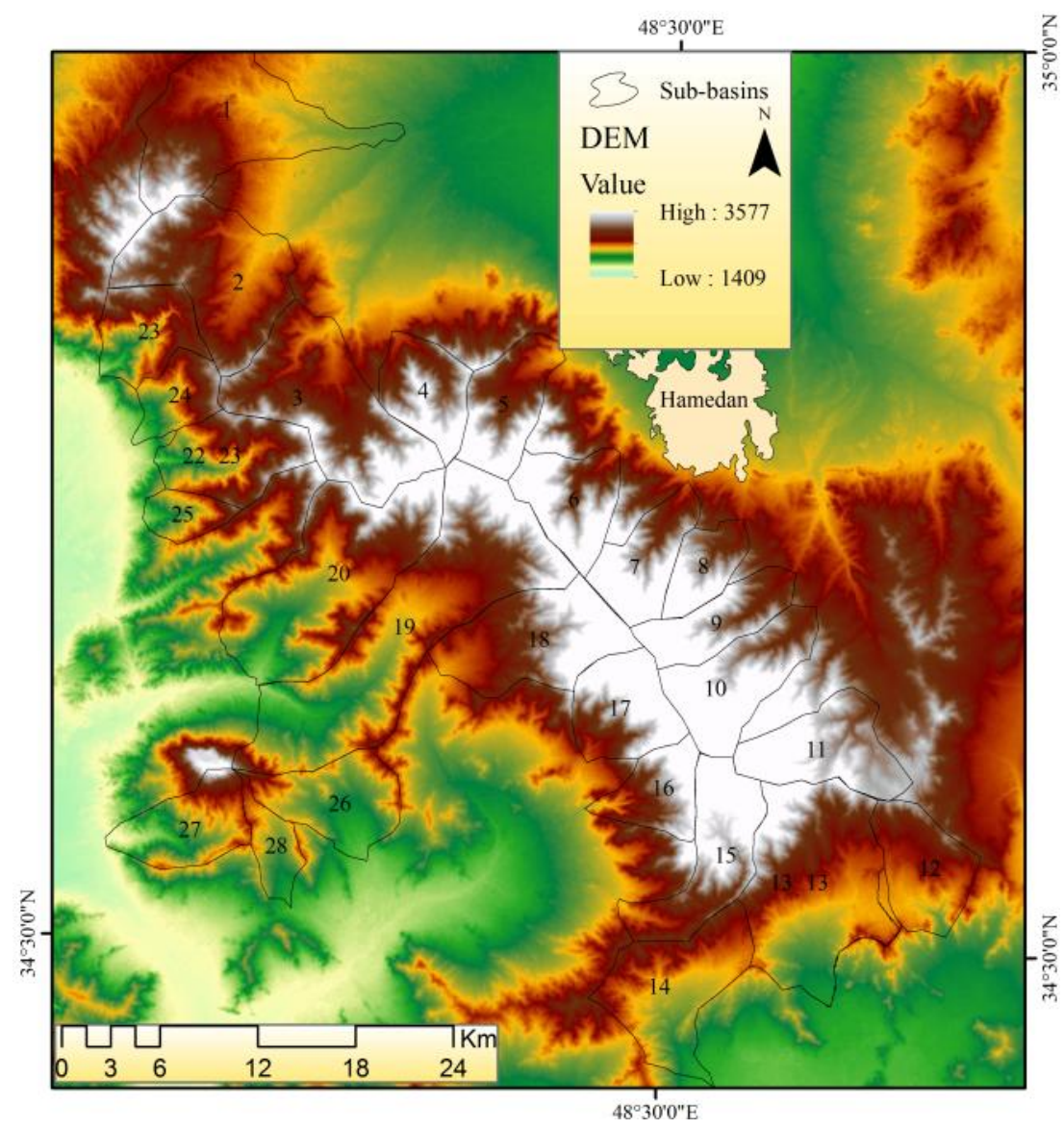

Figure 3. Sub-basin of Alvand Mountain

For further analysis, the contour lines with $50 \mathrm{~m}$ intervals were selected along the main stream. From the peak toward the lowlands, the first contour line with no straight form was selected, and later the length of the part which were located in the watershed was measured. Then, Equation 6 was used to estimate CC (Jafari and Rostamkhani, 2015).

$$
\mathrm{CC}=\frac{\mathrm{a}}{\mathrm{b}}
$$

$\mathrm{CC}$ is the ratio between the aerial (a) and the actual distance of a curve (b) within a valley. Estimated values vary between 0 and 1 . Thus, the estimated coefficient in a contour with low intensity and frequency in the process during the set time will be closer to 1, and if the processes mostly occur along the thalweg, the estimated coefficient will be closer to 0. Investigation of the linear relationships between the estimated coefficients and altitude implies the ascending and descending distribution of the coefficients with respect to altitude. The altitude of this trend change was considered as the ELA. 


\section{Altitude-ratio (AR) and accumulation-area ratio method (AAR)}

In the median-altitude variant of altitude-ratio method, ELA lays midway in the altitude between the head of the glacier (Ah) and the terminus (At). In the terminushead altitude ratio (THAR) approach, the THAR equals the ratio of the altitude difference between the terminal and the ELA divided by the total altitude range of the glacier. ELA can be estimated by adding the altitude of the terminus to the product of the total altitude range and an assumed THAR. The use of accumulation-area ratio (AAR) method is based on the ratio of the accumulation area (Sc) to the total area of the glacier (where $S a$ is the ablation area). Empirical studies suggest that a steady-state (SS, when the mass balances 0) AAR of $0.65 \pm .15$ is appropriate for more temperate, relatively debris-free glaciers. The surface topography of the former glacier is reconstructed based on glacial-geologic data. ELA value is obtained from glacier's areaaltitude distribution (here depicted as a cumulative curve) and an assumed AAR (Fig. 4).
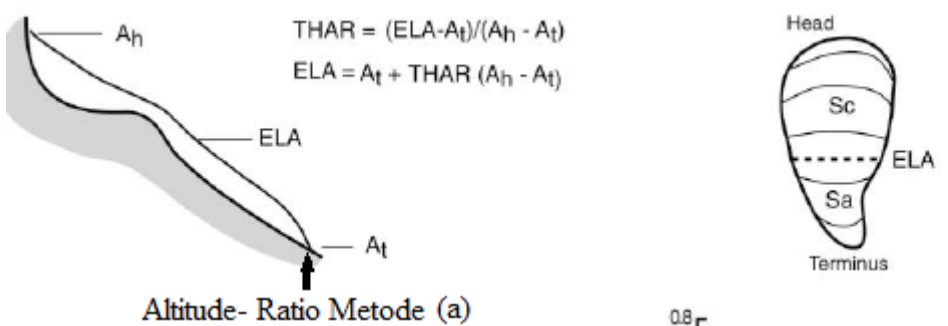

$$
\mathrm{AAR}=\frac{\mathrm{Sc}}{\mathrm{Sc}+\mathrm{Sa}}=0.65
$$

Altitude- Ratio Metode (a)
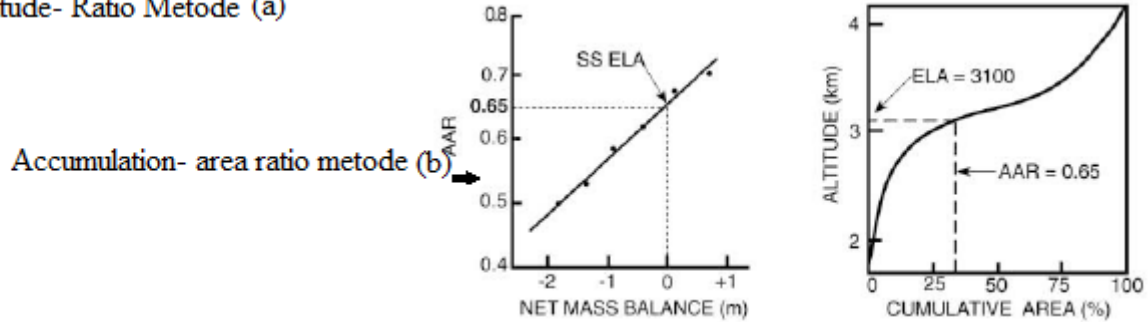

Figure 4. AR and AAR method used to derive past equilibrium-line altitudes in the tropics.

(Adopted from Porter, 2001)

\section{Results and discussion}

\section{ELA estimation of Alvand Mountain by Wright method}

Iran's Alvand Mountain, which is above $3500 \mathrm{~m}$ and possess different forms of cirques, is one of the ancient glacial cirques in mountainous regions and can be employed for estimating ELA. In the study area of this research by studying the topographical maps the numbers and positions of cirques were determined through the contour lines. Accordingly, ELA for Alvand Mountain were estimated. Then the number of cirques was separately identified in both northeast and southwest slopes and their ELA was estimated. Investigations revealed that cirques in the southwest slope (100 cirques) have been decreasing at an altitude between 1700 to $2900 \mathrm{~m}$, and their number has been decreasing up to $2300 \mathrm{~m}$. Whereas cirques in the northeast slope (162 cirques) have been decreasing at an altitude between 1900 to $3300 \mathrm{~m}$, and their number has been decreasing up to $2200 \mathrm{~m}$. According to Wright Method, ELA was estimated at $2294 \mathrm{~m}$ for the entire study area of this research. Also, ELAs of 2404 and $2246 \mathrm{~m}$ were estimated for northeast and southwest slopes, respectively (Fig. 5). 


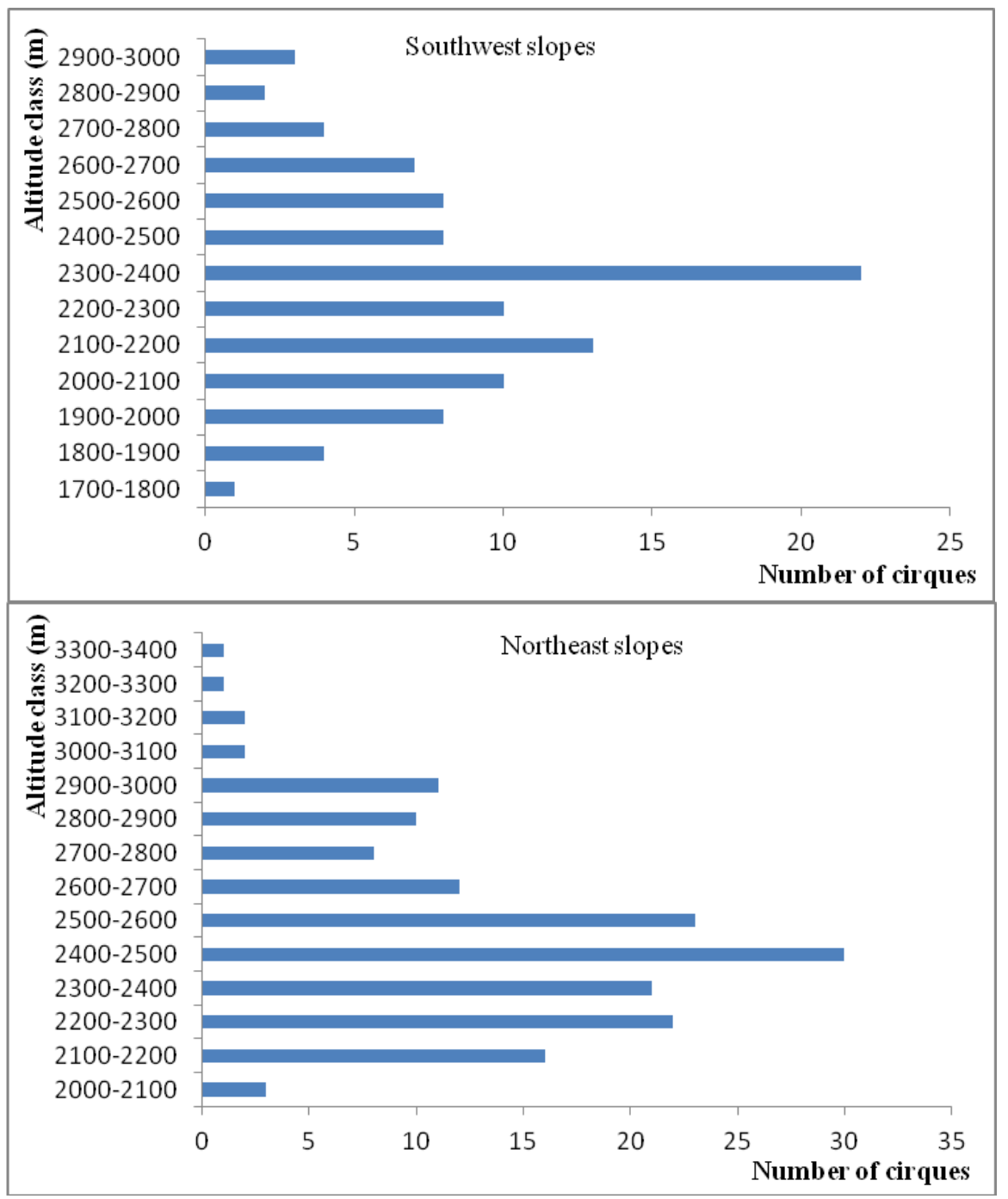

Figure 5. The distribution of cirques altitude at northeast and southwest slopes

\section{ELA estimation of Alvand Mountain by slope-direction method}

The amount of slope is very important in the Slope-Direction (SD) method. The GIS estimated average slope for northeast and southwest were $10.035 \%$ and $13.73 \%$, respectively. The calculated slope was placed in Equations 3 and 4 and eventually their temperatures were estimated. Estimated temperatures were placed in Equation 5 and their altitude was obtained.

$$
\begin{array}{ll}
\mathrm{T}=10.84-10.035(0.11) & \mathrm{T}=9.74^{\circ} \mathrm{C} \\
\mathrm{T}=11.27+0.09(13.73) & \mathrm{T}=12.5^{\circ} \mathrm{C}
\end{array}
$$

Contemporary ELA in northeast slopes:

$$
X=\frac{9.74(1000)}{5.2}=1873.07+1741.5=3614
$$


Contemporary ELA in southwest slopes:

$$
X=\frac{12.5(1000)}{5.2}=2403.84+1741.5=4145
$$

ELA in northeast slopes:

$$
T=9.74-8.5=1.14^{\circ} \mathrm{C} X=\frac{1.14 \times 1000}{5.3}=219.03+1741.5=1960
$$

ELA in southwest slopes:

$$
T=12.5-8.5=3.9^{\circ} \mathrm{C} X=\frac{3.9 \times 1000}{5.3}=735.84+1741.5=2491.5
$$

ELA will be achieved using Equation 5. Thus, the average ELA was obtained at 1960 and $2491 \mathrm{~m}$ for northeast and southwest slopes, respectively, which were about $530 \mathrm{~m}$ higher in southwest slopes.

\section{ELA estimation by CC method}

In this method, GIS software was used to draw the mountain sinuosity on topographical maps of 1.50000 . The mountain valleys were separated into 28 subbasins. In all sub-basins, the contour lines with $50 \mathrm{~m}$ intervals were selected along the main stream. From the peak toward the lowlands, the first contour with no straight form was selected, and the length of part located in the basin was measured (b). Then, Equation 6 was used to estimate CC. CC is the ratio between the aerial (a) and the actual (b) distance of a contour in a valley. Fitted values of the linear regression between the estimated coefficients and altitude denote the ascending and the descending distribution of the coefficients with respect to the altitude. The altitude at which this trend change was considered to be the lowest point of the $\mathrm{CC}$, the altitude of which matches ELA. The CC status at low altitude was also examined with respect to the dominant peak in the basin. To evaluate the geomorphologic processes over time, curvature coefficients were compared in all sub-basins using Equation 6. Linear regression was fitted between altitude, as an independent variable, and curvature, as a dependent variable. The results show that $\mathrm{CC}$ had specific trends in most sub-basins. The estimated CC was close to 1 on the slopes, and it decreased with increasing altitude (Figs. 6 and 7). With increasing distance from the basin outlet, first the coefficient reached with minimum and then increased again.

As it is evident in Figures 6 and 7, the lowest altitude of CC (0.31) is located at $2500 \mathrm{~m}$ altitude (No. 19, Shahrestaneh Valley) and the maximum value of this coefficient $(0.8)$ is located at $3300 \mathrm{~m}$ altitude. The amount of this coefficient reduces from the mountain peak up to $2400-2500 \mathrm{~m}$, and it increases again toward the basin outlet (Table 3). This process is also affected by the topography of the region. The altitude of these changes was estimated $2400 \mathrm{~m}$ in northeast slopes and $2400-2500 \mathrm{~m}$ in southwest slopes in most of the sub-basins. As the peak altitude reduces, the lowest amount of the coefficient shifts toward the lower altitudes. Table 3 indicates the lowest altitude diagrams for each sub-basin. Where the sub-basins' slope direction is inclined north, the lowest altitude in the diagrams is expected to be in sub-basins number $4,6,8$, 
$9,10,11,16,17,20,22,27,26$, and 28 . For example, the minimum altitude located at sub-basin number $26(1750 \mathrm{~m})$ with estimated weigh value of $96^{\circ}$ tends toward the north. The maximum altitude at sub-basin number $7(2450 \mathrm{~m})$ with estimated weigh value of $179^{\circ}$ completely tends toward the south.

Roughness within the basin will be affected by the solar elevation angles. Air masses will also affect the region and precipitation currents in different forms, the outcome of which will be reflected in contour lines. Consequently, Quaternary glacial processes had greater impacts on the northeast slopes. In comparison with the southwest slopes, the lowest altitude was located at a lower altitude.

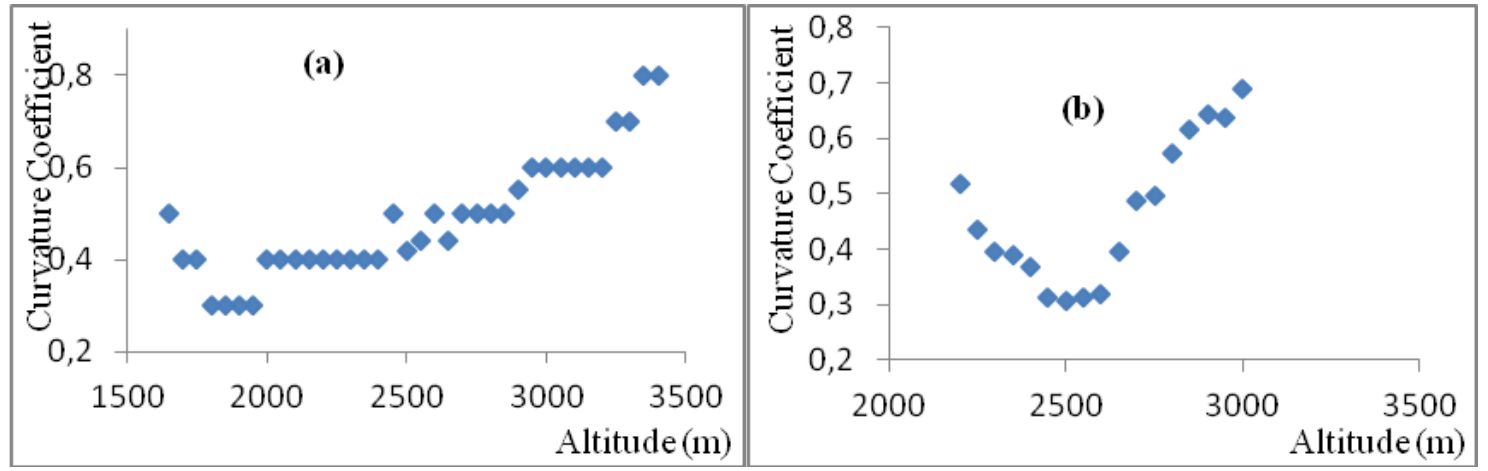

Figure 6. Distribution of the curvature coefficients with respect to the altitude (a) in all subbasins (b) sub-basin N 19

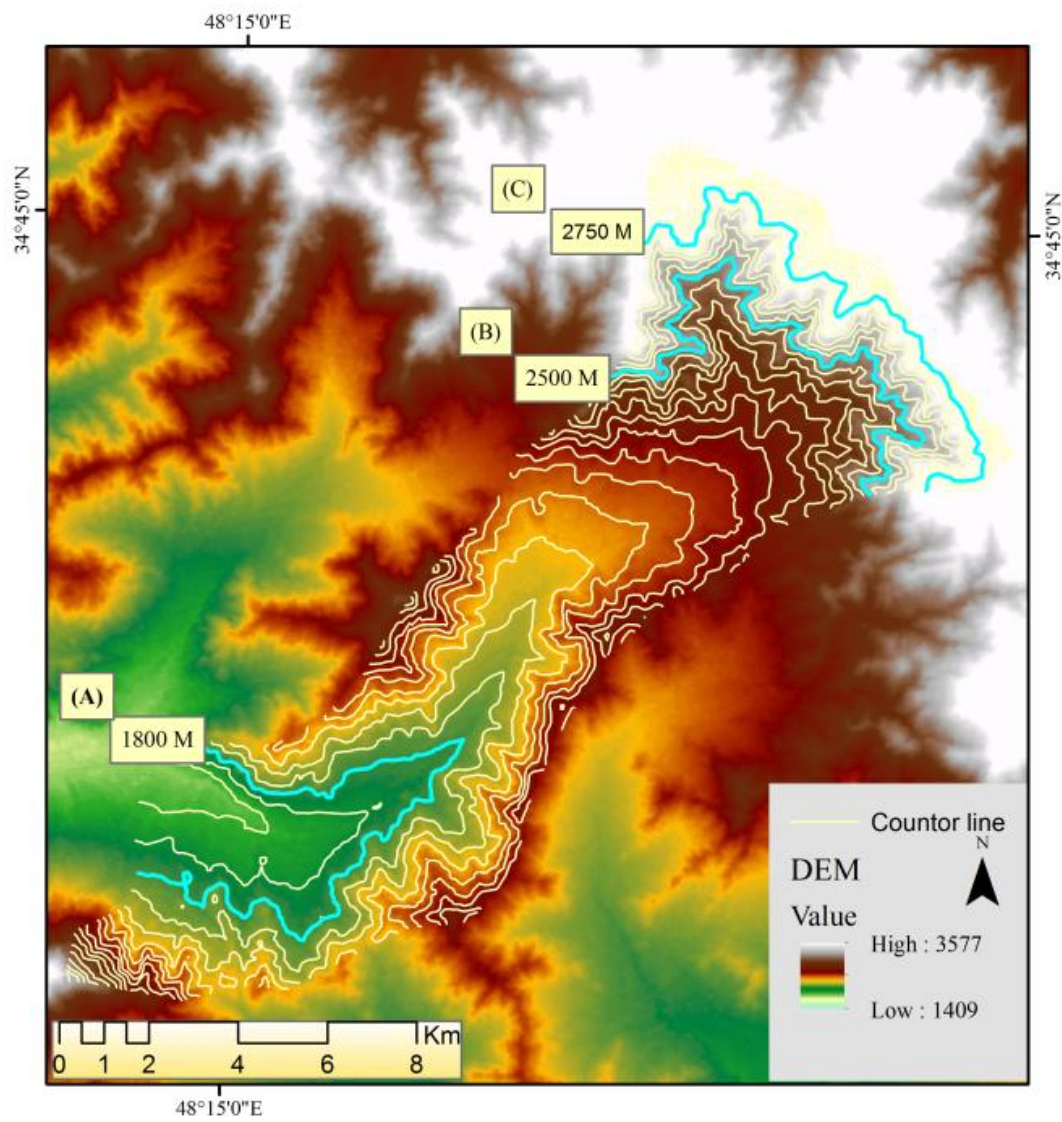

Figure 7. Contour lines and curvature CC in one of the sub-basins 
Table 3. Fitted perigee altitude with CC (Alvand Mountain sub-basins)

\begin{tabular}{c|c|c|c|c|c}
\hline $\begin{array}{c}\text { Number of the sub- } \\
\text { basin }\end{array}$ & Altitude range & $\begin{array}{c}\text { Lowest } \\
\text { altitude }\end{array}$ & $\begin{array}{c}\text { Number of the sub- } \\
\text { basin }\end{array}$ & Altitude range & $\begin{array}{c}\text { Lowest } \\
\text { altitude }\end{array}$ \\
\hline 1 & $1950-2750$ & 2400 & 15 & $1950-32300$ & 2150 \\
2 & $2000-2800$ & 2150 & 16 & $2000-3200$ & 1200 \\
3 & $1950-3000$ & 2100 & 17 & $2150-3350$ & 1200 \\
4 & $2200-3200$ & 2200 & 18 & $2450-3350$ & 2400 \\
5 & $1950-3000$ & 2400 & 19 & $2150-3000$ & 2500 \\
6 & $2050-3100$ & 2050 & 20 & $1750-3000$ & 1250 \\
7 & $2050-3250$ & 2450 & 21 & $1600-2600$ & 2150 \\
8 & $2150-3000$ & 2150 & 22 & $1700-2600$ & 1700 \\
9 & $2150-3250$ & 2150 & 23 & $1650-2450$ & 1800 \\
10 & $2200-3200$ & 2200 & 24 & $1800-2400$ & 2050 \\
11 & $2300-3350$ & 2350 & 25 & $1650-2350$ & 1850 \\
12 & $1900-2450$ & 2150 & 26 & $1600-2600$ & 1750 \\
13 & $1800-3100$ & 2250 & 27 & $1850-2050$ & 1850 \\
14 & $1650-2300$ & 1850 & 28 & $1800-2200$ & 1800 \\
\hline
\end{tabular}

In order to estimate the altitude variations, they were classified into four classes of $3500,3400,3200$, and $2800 \mathrm{~m}$. A linear relationship was fitted between the altitude of the mountain peaks, as an independent variable (X), and the lowest altitude, as a dependent variable (Y) (Eq. 8). According to this equation, it can be expressed that the low altitude increases by about $51 \mathrm{~m}$ for every $100 \mathrm{~m}$ altitude. The sub-basins were classified into seven groups based on the dominant geographical direction in the main valley. Also, the average lowest altitude (the altitude at which the $\mathrm{CC}$ varies) and the average $\mathrm{CC}$ were estimated in the same directions for each group (Table 4). To estimate the relationship between the average geographical direction and the average lowest altitude, Equation 8 was used and Equation 9 was applied to estimate the CC and the average lowest altitude.

Table 4. CC and altitude values according to different geographical directions

\begin{tabular}{c|c|c|c|c|c|c|c}
\hline Directions & WSW & SSE & S & NNE & ENE & N & E \\
\hline Average lowest altitudes & 2167 & 2150 & 1980 & 2263 & 2200 & 2250 & 1957 \\
Average CC & .47 & .4 & .52 & .47 & .35 & .4 & .52 \\
\hline
\end{tabular}

$$
\begin{aligned}
& Y=-1.0968 x+2242 \\
& Y=-0.0004 x+1.227
\end{aligned}
$$

Accordingly, it was revealed that as the sub-basins' geographical direction stretches toward the north, the lowest altitude increases in the curvature coefficients (Table 3 and Eqs. 8 and 9). This altitude was estimated at 2242 and $2044 \mathrm{~m}$ for the valleys that completely lean towards the south. This represents the glacial impact on the northeast and southwest slopes, which varies according to the environmental conditions. The 
accumulation of glaciers emanated from the cirques above the ELA indicates a better condition in the topography of southwest slopes. Hence, the lower altitudes move toward the lower altitudes in comparison to the northeast slopes. Although the southwest slopes of Alvand Mountain have lower CC altitude, its CC value is much lower for the glacial processes were less effective on the highlands. Accordingly, the average lowest altitude was $2130 \mathrm{~m}$ in the entire area, and 2000 and $2146 \mathrm{~m}$ in the northeast and southwest sub-basins, respectively.

The matter and energy distribution have been usually uniform from the Mountain peak down to the slopes. In the V-shaped valleys, the CC became close to zero. In the glacial valleys, although the glacier thickness increases, the concentration of the matter and energy did not occur in the thalweg. By investigating $\mathrm{CC}$ in the 28 sub-basins of Alvand Mountain, it was revealed that the descending trend of the $\mathrm{CC}$ was expected to the point where matter and energy (glacial ice) are concentrated, and later from that altitude, the $\mathrm{CC}$ is increasing. In the sub-basin, where the slopes lengths are considerable (the southwest slopes), the lowest altitude of the CC varies based on the highest peak in the area. In the valleys that the highest peaks are more than $3400 \mathrm{~m}$, the altitude of change CC is between 2400 and $2500 \mathrm{~m}$. As if the tallest peak in the subbasin is less than 3400 , the altitude of change CC decreases.

\section{ELA estimation by AR and AAR Method}

For estimating ELA of Alvand Mountain via AR and AAR Method, a profile of cirques' floor was detected by global mapper software. If the profile is a concave, landform is considered as cirque. In field observation, the beginning literate moraines were determined. Their record was positioned by GPS and the data transferred to GIS. Through field observations, cirque number 42 was detected in northeast slope, cirque number 25 was detected in the southwest, and $A t$ was estimated. To obtain altitude and determine Ah in the profile (Fig. 8), ELA was estimated and translated into equations related to THAR and AAR. Based on AAR method, the estimated ELA for northeast slopes is $2297 \mathrm{~m}$ and for southwest slopes is $2727 \mathrm{~m}$.

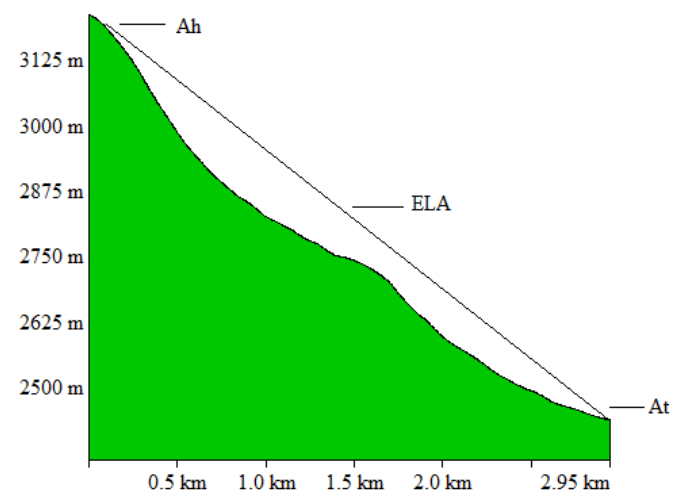

Figure 8. sample of profile in Alvand Mountain

\section{Water and ice equilibrium line altitude (WIELA)}

Values of erratic block and paleo-climates have been investigated as archive of historic glacial activity and as ice glaciers, respectively (Millar and Westfall, 2008). Large terminal moraines mark the outer limit of the ice sheet. In some places, the 
terminal moraine is a single ridge; in other places, it may be a series of sub parallel ridges. There may be a large sandar (outwash plains) leading away from the terminal moraines wherever sub glacial or supra glacial streams emerge from the ice margin. The terminal moraines can be used to reconstruct the size of the ice sheet at its maximum extent (Bennett and Glasser, 2009: 367). There are moraine terminals around Alvand Mountain that can be used to estimate the WIELA in the longest glacial period in the Quaternary. For this purpose, several major paths of the erratic block were chosen in the northeast and southwest slopes and their expansion was investigated. Field survey revealed that the WIELA in the longest glacial period in the southern slopes was placed at $1680 \mathrm{~m}$, and erratic block evidence has been detected in northeast slopes (1776 m). In the middle latitudes of the Northern Hemisphere (like Iran), the most suitable places for the cirques are topographical hollows facing northeast. The most extensive glacier of the Alamkouh is located on the northeast side and constitutes permanent glacial (Zomorodian, 2012).

In this regard, consideration of environmental gradients and topographical conditions (features that affect the ice flow velocity and moves WIELA to the lowlands) is highly recommended. The greater the slope, the greater the increase in glacier flow velocity is. Thus, it takes more time to achieve a balance between the flows and melt velocity. The second feature is the topography on the front side of the mountain that will accumulate more ice and consequently, be thicker and faster ice flow in favourable conditions. As a result, it limited the lateral extent of ice and prevented melting. These two features indicate the slope of the southwest slopes leads to ice accumulation and valley glacier formation. Although there is no appropriate condition for the glacial formation in the northeast slopes, the valleys come together after the mountain knick. Hamedan topographical similarities with a large cirque (with a radius of $3.3 \mathrm{~km}$ ) imply that if the glacier tongues were fed well and accumulated, it could not overflow for the low slope gradient. The existence of the erratic block in different parts of Hamedan is an evidence for this claim (Fig. 9).
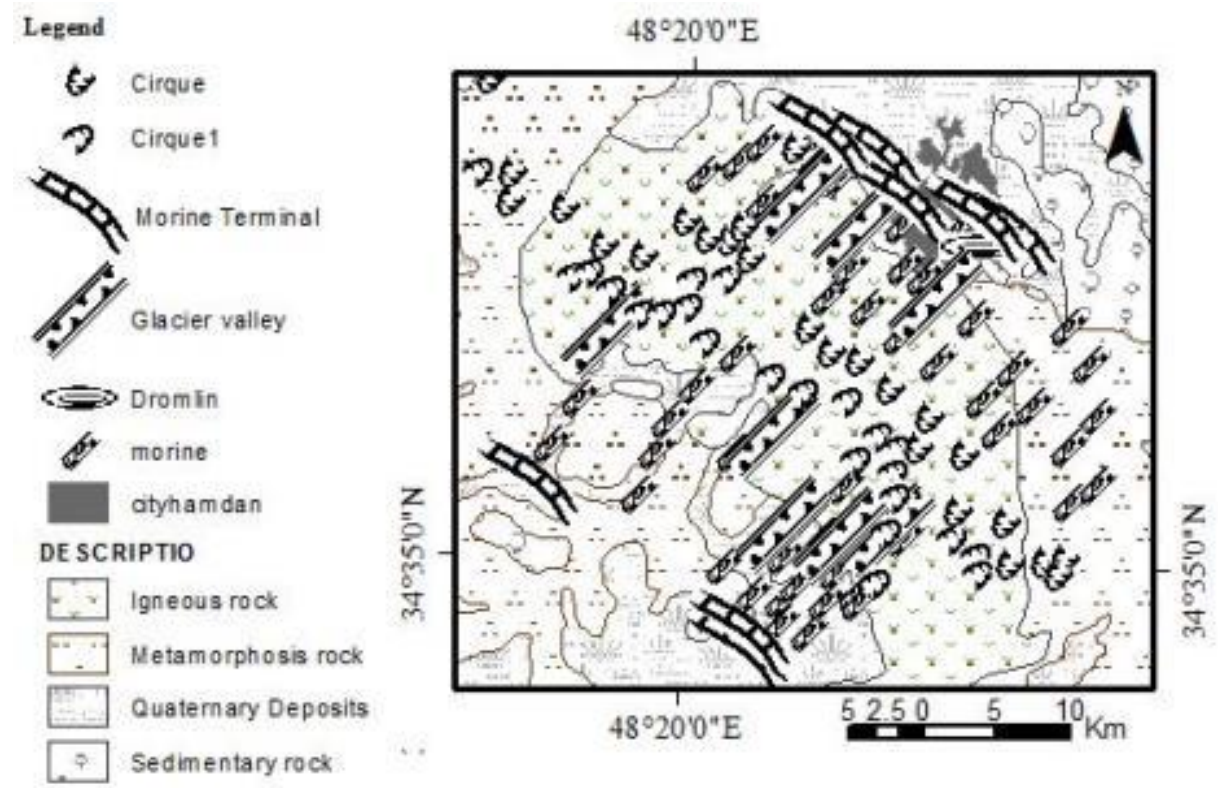

Figure 9. Geomorphologic map of maximum expansion of Quaternary glaciers in Alvand Mountain 


\section{Conclusion}

Wright method is often used for estimating the Quaternary ELA of the Iranian mountains. Four methods have used to test this method in an Alvand Mountain (SD, CC, AAR and THAR). The ELA of Alvand Mountain estimated using the Write method indicates that the ELA of the northeast slopes is above the ELA of the southwest slopes. While, given the position of Iran in the temperate region of the northern hemisphere, the ELA in the northeast slopes should be in lower heights than the southwest slopes. The ELA estimated using the CC method in the northeast slopes is 68 meters above the southwest slopes, such a difference, like the Wright method, cannot be accepted with regard to environmental conditions. The non-conformance of ELAs estimated using Wright and CC methods with environmental conditions is due to differences in altitude of mountainous sinusitis in two northeast and southwest slopes. The sinusitis elevation in the northeast slopes is $2000 \mathrm{~m}$ and $1700 \mathrm{~m}$ in the southwest slopes. The $300 \mathrm{~m}$ difference of the sinusitis altitude has led to the identification of the cirque up to $1700 \mathrm{~m}$ in the southwest slopes and its identification up to $2000 \mathrm{~m}$ in the northeast slopes. The identification of the cirques at different heights of the two slopes led to estimate a lower ELA in the northeast slopes compared to the southeast slopes. The beginning of the pediment at an altitude of $2000 \mathrm{~m}$ in the northeast slopes in the Cc method has led to a higher ELA estimation of northeast slopes compared to southwest slopes. In the Cc method, the ELA is estimated based on the contour line forms. The result is that these two methods cannot be used for ELA estimation in areas where sinusitis height is above the maximum expansion of the Quaternary glacial. Estimated ELA for northeast slopes by the SD method is $513 \mathrm{~m}$ lower than the estimated ELA on the southwest slopes. Such a difference is justifiable with regard to the sun's altitude angle in the northeast slopes. The ELAs Estimated through both AAR and THAR methods were similar. That is why the AAR method is just presented. The ELA estimated using the AAR method in the northeast slopes is $430 \mathrm{~m}$ lower than the estimated ELA of southwest slopes (Fig. 10 and Table 5). The results of using SD and AAR methods for ELA estimation are consistent with the findings of Jafari (2013), Moayeri et al. (2011), and Ramesth (2002). Therefore, these two methods can be used to estimate ELA.

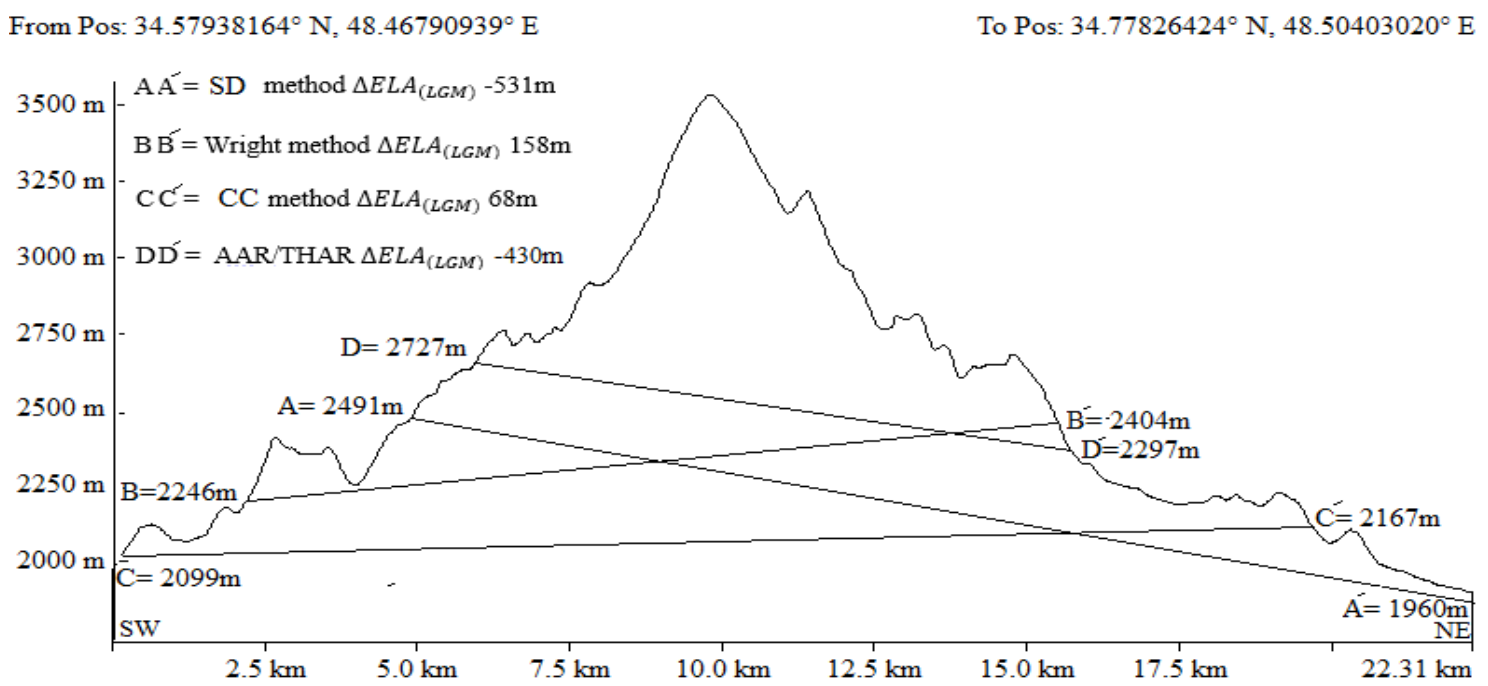

Figure 10. The past ELA estimated by the Wright, SD, and curvature coefficient methods 
Table 5. The comparisons of ELA in Alvand Mountain

\begin{tabular}{c|c|c|c}
\hline Method & Total & Northeast slope & Southwest slope \\
\hline CC & 2138 & 2167 & 2099 \\
Wright & 2294 & 2404 & 2246 \\
SD & 2226 & 1960 & 2491.5 \\
AAR & 2512 & 2297 & 2727 \\
\hline
\end{tabular}

In addition to the ELA, WIEA has been also estimated in the present study. WIEA was detected using erratic blocks. The WIEA estimated in the southwest slopes was $1680 \mathrm{~m}$ and on the northeast slopes was $1780 \mathrm{~m}$. Glacial's tongues in the southwest slopes than the northeast slopes have flowed until a lower altitude. The reason is due to the differences between the topography of the pediment of the southwest and northeast slopes. The topography of the southwest slopes causes glacial's tongues to be connected and creates a glacial valley. Whereas, the topographic conditions of the pediments of the northeast slopes have led to the creation of a glacial sheet (ice sheet) instead of a glacial valley. The flow velocity in the glacial sheet is less than the flow velocity of the glacial valley due to the less thickness. As a result, in the maximum expansion of the WIEL, the topographic conditions of the pediment were more effective than the direction of mountain slopes.

\section{REFERENCES}

[1] Abramowski, U., Bergau, A., Seebach, D., Zech, R., Glaser, B., Sosin, P., ... Zech, W. (2006): Pleistocene glaciations of Central Asia: results from 10 Be surface exposure ages of erratic boulders from the Pamir (Tajikistan), and the Alay-Turkestan range (Kyrgyzstan). - Quaternary Sci Rev 25(9): 1080-1096.

[2] Abtahi, S. M. (2014): Investigating the Jajroud watershed palaeoclimate by using the glacial evidence. - Geographical Explore in Desert Areas 1(1): 185-201.

[3] Almodaresi, S. A., Ramesht, M. H. (2007): Glacial evidence in Sakhvidi valley of Yazd. - Geography Space 19: 93-107.

[4] Amirahmadi, A., Maghsodi, A., Ahmadi, T. (2011): Evaluating the effects of Quaternary glaciers on the lack of civilization and main urban habitation in Aspas plain. - Urban - Regional Studies and Research Journal 3(10): 61-80.

[5] Benn, D. I., Evans, D. J. A. (2010): Glaciers and Glaciation. - Hodder Education, Abingdon.

[6] Benn, D. I., Lehmkuhl, F. (2000): Mass balance and equilibrium-line altitudes of glaciers in high-mountain environments. - Quaternary International 65: 15-29.

[7] Bennett, M. R., Glasser, F. N. (2009): Glacial Geology, Ice Sheets and Landforms (2nd ed.). - Wiley-Blackwell, Chichester.

[8] Bobek, H. (1934): Reise in Nordwest Persien 1934 (Travel in northwest Persia). Zeitschrift der Gesellschaft fur Erdkunde zu Berlin 9(10): 359-369.

[9] Bobek, H. (1963): Nature and implications of Quaternary climatic changes in Iran. Changes of Climate 20: 403-4013.

[10] Bondarenko, O. V., Blokhjna, N. I., Utescher, T. (2013): Quantification of Calabrian climate in southern Primory'e, Far East of Russia. An integrative case study using multiple proxies. - Palaeogeography, Palaeoclimatology, Palaeoecology 386: 445-458.

[11] Clark, P. U., Dyke, A. S., Shakun, J. D., Carlson, A. E., Clark, J., Wohlfarth, B., ... McCabe, A. M. (2009): The last glacial maximum. - Science 325(5941): 710-714. 
[12] Desio, A. 1934. Appunti geografici e geologici sulla catena dello Zardeh Kuh in Persia. - Memorie Geologiche e Geographiche di G. Dainelli 4: 141-167.

[13] Esfandiari Dur Abadi, F. (2009): Geomorphological evidence of Upper Pleistocene climate change in the easterly slope of Sabalan. - Physical Geography Research Quaternary 3: 83-96.

[14] Fu, P., Harbor, J. M., Stroeven, A. P., Hättestrand, C., Heyman, J., Zhou, L. (2013): Glacial geomorphology and paleoglaciation patterns in Shaluli Shan, the southeastern Tibetan Plateau-Evidence for polythermal ice cap glaciation. - Geomorphology 182: 66-78.

[15] Ghahroudi Tali, M., Abdoli, E., Nezammahalleh, M. A. (2013): Geomorphological and Sedimentological evidence of alpine glaciers in the Zagros Mountains, Dinevar, Iran. Tethys 1(1): 85-95.

[16] Head, M. J., Gibbard, P. L. (2015): Formal subdivision of the Quaternary system/period: Past, present, and future. - Quaternary International 383: 4-35.

[17] Headley, R. M., Ehlers, T. A. (2015): Ice flow models and glacial erosion over multiple glacial-interglacial cycles. - Earth Surf Dyn 3(1): 153.

[18] Jafarbeglu, M., Yamani, M., Abbasnegad, A., Zamznzadeh, M., Zahabnazoury, S. (2014): Reconstruction of Quaternary snow line in Bid Khan mountain (Kerman province). - Geography Quarterly 12(40): 93-107.

[19] Jafari, G. H. (2009): The Effect of the Roughness's on the Quaternary WIELA. University of Isfehan, Department of Geography.

[20] Jafari, G. H. (2013): Estimating the ELA with Iran. - Geography and Environmental Planning 4(24): 99-115.

[21] Jafari, G. H., Asghari, S. (2014): Analysis the effects Quaternary glacial Zanjanrood. Quantitative Geomorphological Researches 2(3): 16-30.

[22] Jafari, G. H., Rostamkhani, A. (2015): Quaternary evolutions of mountain valleys by using contour lines case study (Sabalan Mountains). - Geography Research Quarterly 118: 121-138.

[23] JedariEivazi, J. (2011): Geomorphology of Iran. - Payame Noor Press, Iran.

[24] Kaser, G., Osmaston, H. (2002): Tropical Glaciers. - Cambridge University Press, Cambridge.

[25] Khosravi, A., Quorbani Shorestani, A., Nur Mohammadiy, A. M. (2016): Study of Quaternary glacial geomorphological evidence in the highlands of North-East of Iran (Case Study: Mountains Binalud). - Quantities Geomorphology Researches 5: 1-13.

[26] Knight, G. P. (2006): Glacier Science and Environmental Change. - Blackwell Science, Oxford.

[27] Mahmoudi, F. A. (2008): Geomorphology of Iran (Vol. 2). - Tehran University Press, Tehran.

[28] Meierding, T. C. (1982): Late Pleistocene glacial equilibrium-line altitudes in the Colorado Front Range: a comparison of methods. - Quaternary Res 18: 289-310.

[29] Millar, C., Westfall, R. D. (2008): Rock glaciers and related per glacial landforms in the Sierra Nevada, CA, USA; inventory, distribution and climatic relationships. Quaternary International 188: 90-104.

[30] Moayeri, M. Ramesht, M. H., Taghvaei, M., Naghizadeh, M. M. (2008): Glacial evidences (case study: SafaShahr, Fars Province). - Geography and Environmental Planning 32(4): 109-130.

[31] Moayeri, M., Ramesht, M. H., Saif, A. Yamani, M., Jafari, G. H. (2011): The impact of mountainous skirts direction of Iran on differences in altitude of wither and ice equilibrium line of the Quaternary. - Geography and Environmental Planning 40(4): 112.

[32] Moghimi, I. (2008): Geomorphology in the Cold and Glacial Territory. - Tehran University Press, Tehran.

[33] Nesje, A., Dahl, O. (2000): Glaciers and Environmental Change. - Arnold, London. 
[34] Nojavan, M. R., Mir Hossini, A., Ramesht, M. H. (2010): Yazd Geotups and its attractions. - Geography and Development 13: 47-60.

[35] Ohmura, A., Kasser, P., Funk, M. (1992): Climate at the equilibrium line of glaciers. Glaciology 38: 397-411.

[36] Osmaston, H. (2005): Estimates of glacier equilibrium line altitudes by the Area $\times$ Altitude, the Area $\times$ Altitude Balance Ratio and the Area $\times$ Altitude Balance Index methods and their validation. - Quaternary International 138-139: 22-31.

[37] Parizi, E., Ramesht, M. H., Taghian, A. R. (2014): Glacial evidence of Late Quaternary in the basin Sirjan Tigroeih. - Quantities Geomorphology Researches 3: 111-128.

[38] Paterson, W. S. B. (1994): The Physics of Glaciers (3rd ed.). - Elsevier, Oxford.

[39] Petersen, J. F., Sack, D., Gabler, R. E. (2017): Physical Geography (11th ed.). Cengage Learning, Brooks Cole, Boston, MA.

[40] Porter, S. C. (2001): Snowline depression in the tropics during the Last Glaciation. Quaternary Sci Rev 20: 1067-1091.

[41] Ramesht, M. H., Kazemi, M. M. (2002): Glacial evidence (case study: Eghlid, Iran). Geographical Education, Growth 4(21): 3-11.

[42] Ramesht, M. H., Nematollahi, F. (2005): Glacier evidences in Iran. - Humanities Educations 9(4): 143-162.

[43] Ramesht, M. H., Shahzeidi, S. (2011): Geomorphology Application in National and Regional Planning. - Isfahan University Press, Isfahan.

[44] Ramesht, M. H., Shoshtari Zadeh, N. (2004): Evidence of ice caps and glaciers in Salafchegan. - Geographical Research 19(73): 119-132.

[45] Seife, A., Servati, M. R., Rahdan Monfared, M. (2015): Restructuring of Late Quaternary snowline in within of site Rige. - Geographical Research 116: 193-208.

[46] Sharifi, M., Farahbakhsh, Z. (2015): Investigation about temperature and humidity anomalies between Pleistocene and present times; reconstruction of climate condition using geomorphic evidence (case study: Khezrabad-Yazd). - Physical Geography Quarterly 47(4): 499-675.

[47] Solomina, O., Barry, R., Bodnya, M. (2004): The retreat of Tien Shan glaciers (Kyrgyzstan) since the Little Ice Age estimated from aerial photographs, lichenometric and historical data. - Geografiska Annaler: Series A, Physical Geography 86(2): 205215.

[48] Stroeven, A. P., Hättestrand, C., Heyman, J., Kleman, J., Morena, B. M. (2013): Glacial geomorphology of the Tian Shan. - Maps 9(4): 505-512.

[49] Tahoni, P. (2005): Geomorphic evidence of Pleistocene glacial erosion in the highlands of Talysh. - Geography Research Quarterly 47: 31-55.

[50] Vaziri, F. (2003): Hydrology in Iran: preliminary identification of the glaciers in Iran (Vol. 2). - Management and Planning Organization Press, Tehran.

[51] Yamani, M. (2002): Geomorphological evidence for glaciers Alamkouh. - Physical Geography Research Quaternary, Tehran University 41: 1-17.

[52] Yamani, M. (2007): Geomorphology of the glaciers in Zardkouh mountain: geomorphologic forms and their extension. - Geographical Research 39(59): 125-139.

[53] Yamani, M., Zamani, H. (2007): Recovery of the Snowline Valley Shahrestanak the last glacial era. - Quarterly Geography 12-13: 99-116.

[54] Yamani, M., Jedari Eyvazi, J., Gorabi, A. (2007): The geomorphological traces of glaciers boundaries in Karkas Mountains. - Spatial Planning 11(1): 207-228.

[55] Yamani, M., Shamsipour, A. A., Jafariaghdam, M. (2011): Reconstruction of the Pleistocene snowline (case study: Jajroud watershed). - Physical Geography Research 43(76): 30-50.

[56] Yokoyama, Y., Lambeck, K., De Deckker, P., Johnston, P., Fifield, L. H. (2000): Timing of the Last Glacial Maximum from observed sea-level minima. - Nature 406: 713-716. 
[57] Zamani, H. (2009): Evidence and Boundaries of Development of the Quaternary Glaciers in Central Alborz. - Doctoral Thesis, Tehran University.

[58] Zomorodian, M. J. (2012): Geomorphology of Iran (Vol. 2). - Mashhad University Press, Mashhad. 